\title{
A WORK OF ART IN THE SPACE OF NETWORK CULTURE: CREATIVITY AS BRICOLAGE
}

\author{
Aynur SAFINA (D) ${ }^{1}$, Liliana GAYNULLINA (D) ${ }^{1^{*}}$, Ekaterina CHEREPANOVA (D) ${ }^{2}$ \\ ${ }^{1}$ Department of History and Philosophy, Kazan State University of Architecture and Engineering, \\ Zelenaya str. 1, 420043, Kazan, Russia \\ ${ }^{2}$ Department of History of Philosophy, Philosophical Anthropology, Aesthetics and Theory of Culture, \\ Ural Federal University, Mira str. 19, 620002, Ekaterinburg, Russia
}

Received 8 July 2019; accepted 27 February 2020

\begin{abstract}
The development of modern informational-communication technologies has led to the occurrence of the new unique sociocultural phenomenon - a network culture, with irony as the dominating rhetoric. In the space of network culture, under digital technologies, the forms, types, and functions of art, and creativity in general, change. The paper states that communication becomes the main function of art, while a work of art more and more becomes an object of communication. The authors propose to broaden the volume of creativity conception, going beyond the classical interpretation towards a broader understanding of this phenomenon, namely, creativity as bricolage. The methodological basis of the bricolage model of creativity, relevant for the new media art, is the concept of "bricolage" developed by Claude Lévi-Strauss.
\end{abstract}

Keywords: bricolage, communication, creation, irony, network culture, new media art.

\section{Introduction}

The epoch between the two world wars of the 20th century is usually defined as the period incredibly fruitful in terms of creativity. Notably, almost simultaneously in 1936, two significant, virtually program, while essentially opposite works on art, nature and essence of a work of art were published. These are the papers by Martin Heidegger The Origin of the Work of Art (German: Der Ursprung des Kunstwerkes, originally published in 1950) and Walter Benjamin "The Work of Art in the Age of Mechanical Reproduction" (1936, originally published in 1935). In the context of the topic under discussion, we focused on the work by Benjamin.

In his work, Benjamin shows that, with the appearance of new technical means, not only the techniques of the works of art reproduction change, but also the very notion of art. Moreover, the new techniques of the works of art reproduction generated a new type of culture - mass culture, by making art more accessible for a common user.

${ }^{\star}$ Corresponding author. E-mail: lianagai@ya.ru

This is an Open Access article distributed under the terms of the Creative Commons Attribution License (http://creativecommons. org/licenses/by/4.0/), which permits unrestricted use, distribution, and reproduction in any medium, provided the original author and source are credited. 
After nearly 100 years, continuing the logic of Benjamin, we have to ponder over the question if changes in art take place due to development of new information-communication and advanced digital technologies, to emergence of the Internet and social media, which became a habitat for works of art. Emergence of new technologies in the second half of the 20th century not only changed the techniques of the works of art reproduction but also generated new genres - digital art.

Finally, the network culture produces also new genres of art - digital art and new media art. Digital art is a special kind of art, created with modern computer technologies and, therefore, implying that the only space of existence of such works of art is digital environment. This kind of art includes such genres as digital painting, hypertext literature, ASCII art, pixel art, demoscene, ANSI art, digital poetry, etc.

The notion close to digital art is new media art. New media art is a broader notion, including not only art created with digital technologies but also with classical means, which, in case of its further digitalization and placing into the digital environment (like the context of social networks), acquires certain new qualities. In the context of this paper we focused on new media art.

This distinction between the narrow and the broad interpretations of digital art as research objects is close to the opposition of "new media" and "cyberculture" by Lev Manovich: "Cyberculture is focused on the social and on networking; new media is focused on the cultural and computing" (2003, p. 16). Unlike Manovich, who focused on "new media", we focus on "cyberculture" in this article.

Besides the emergence of new media art, the development of information-communication and digital technologies resulted in forming a peculiar type of culture - network culture. The notion of "network" is also used in various meanings: in the broad sociological meaning to denote a peculiar structure of social contacts, inherent to the society in any historical epochs, and in a more narrow sense, characteristic for the modern informational society, to denote various social networking services existing in the online space only, like Twitter, Facebook, etc. Hence, it is necessary to specify the notion of network culture. In this article, we will view network culture as a kind of culture appearing in cyberspace during virtual communication between the members of online communities in social media, chats, forums, etc. (see Safina, 2017). The network culture is a specific kind of communication, presenting and perceiving information in the Internet, including the rules of communication between the members of online communities, specific ethic norms, esthetic canons, and language. It should be noted that the feature of network culture is that any work of art (even if initially created without using information-communication technologies), being digitalized and getting into the space of network culture, undergoes significant metamorphoses. Network culture is not just an external, indifferent context of new media art existence - it determines the specificity of a

\footnotetext{
${ }^{1}$ It should be noted that in his further works Manovich, analyzing the development of "new media" in the digital epoch, came to the conclusion that "the software for making and editing and the digital processes for producing cultural objects gradually substituted all previous types of cultural tools" (2017, p. 8). Within his concept of "cultural software", he introduced the notion of "software culture", which is not reduced to digital art or new media technologies only. The software, which Manovich figuratively calls the universal engine of modern world, provides various cultural practices, including social networking (2013, p. 23).
} 
work of art circulation, the features of its perception by a spectator, the relations between the author and a spectator, and the functions of art.

Moreover, one may assume that the appearance of new media art should lead if not to changing then, at least, to broadening of the very notion of art, which is a generic notion for the new kinds of artistic creativity.

Scientific novelty consists in the attempt to show how digital communication technologies may influence the ontology of an artistic creation, as well as to demonstrate the new aspects of creativity phenomenon, revealed in the very being of an artistic creation in the context of network culture.

\section{Literature review}

When analyzing the topic, the authors relied on the understanding of the essence of art, its interrelation with historical conditions in the broad context, including the technological bases presented in the works by Benjamin (1936), Kandinsky (1910), on the tradition of researching the informational society and network communication formats, originating from the works by Bell (1973), McLuhan (1964), McLuhan and Fiore (1967), Toffler (1980), and Castells $(2000,2001)$. The paper continues the vector of critical review of media-technologies set by Barbrook and Cameron (1996) and Carr (2004). To reveal the specificity of network culture, the authors turned to the works by Lovink (2009, 2013), Boyd and Ellison (2007), Safina (2017), and Safina, Leontyev, Gaynullina, Leontyeva, and Khalilova (2018). The formation of creative society and its criteria, the empirical indices, including individual creativity, were considered in the works by Florida (2002), Howkins (2007), and Kačerauskas (2017); their dialectical interaction with the network culture and new forms of art is presented in the works by Fürst, Ghisletta, and Lubart (2012), Lavrinec (2014), and Pryshchenko (2019). Analysis of transformation of the digital communication technologies influence on art, of the change of its essence and functions under new conditions was carried out relying on the works by Campanelli (2010), Erofeeva and Fedorov (2014), Coeckelbergh (2018), Shanken (2016), and Skidan (2007). When analyzing the transformations which the "author-spectator" relations undergo within network culture, we took into consideration the ideas by Barthes (1967) and Martynov (2015).

\section{Results and discussion}

\subsection{A work of art in the context of network culture}

The specificity of new media art is determined not only by technical means used to create and/or reproduce a work of art, but also the features of the cultural context (network culture). Below we consider these features of network culture.

An essential specific feature of network culture is, first of all, its transnational and exterritorial character. Here a perpetual mixing of ethno-cultural codes and symbolic rows from various epochs takes place, as well as creation of new realities and spaces. At that, the cultural codes and symbolic rows do not only neighbor each other but interact, intricately overlap 
each other, sometimes even unintentionally (beyond the author's will). As a result of such interaction, some new meanings may occur or some additional content may be revealed in the works already created. For example, a social media user wondered how one of his friends could be a member of Britney Spears fan-group and an admirer of Joseph Brodsky's poetry. Indeed, the combination of such diverse cultural layers makes one imply the presence of some implicit meanings in each of them.

The second feature of network culture is impossibility to find the original source of information. Although the Net once appeared to establish and maintain contacts between personified communicants, today it is an anonymous community, where each member may have several names and express opposite views. The result is that sometimes it is impossible to determine the author of a work of art and according to a figurative expression by Kačerauskas, on the Internet, "a thought without an author begins its destructive life of a tramp" (2009, p. 94).

Third, the practices of vision change under the influence of network culture. The so-called "technogenic sensuality" is formed (Skidan, 2007), which means that a person sees and estimates the surrounding world exclusively as represented on a gadget screen. Moreover, an event is assessed from the viewpoint of its network impact, stupefaction. That is why a person more and more often desists from activity, choosing the role of a video operator to post a video online as soon as possible.

Finally, the network culture produces also new genres of art - digital art and new media art. Digital art is often defined as a new kind of art, created with modern computer technologies and, therefore implying that the only space of existence of such works of art is digital environment. This kind of art includes such genres as digital painting, hypertext literature, ASCII art, pixel art, demoscene, ANSI art, digital poetry, etc. Unlike digital art, new media art is a broader notion, including not only art created with digital technologies but also with classical means, which, in case of its further digitalization and placing into the digital environment (like the context of social networks), acquires certain new qualities. In the context of this paper we focused on new media art.

The digital technologies and the new media art significantly influenced both the process of creating a work of art and its perception, or, to be exact, the "author-spectator" relationships. The closest effect of network influence is openness and availability of art in the virtual space. Everything which is digitalized can be seen any time, any place. Any enquiry - of an expert or a layman - can be fulfilled almost immediately, providing the opportunity to listen, read, or watch. New abilities appeared for the author, too - their way to a spectator reduced to "one click". But that is not the only result of network culture development.

In the world of traditional art, the author had always been a sacral figure, to whom the mystery of creative process gave a special status. The spectator, not possessing the mystery of art, always occupied the passive position. Although the serial production of works of art, described by Benjamin, made the consumption of works of art a mass process, still this mass remained a "silent majority" (using a free allusion to a well-known term by Baudrillard (2007), infinitely far from the author.

Today's network forms of communication, as well as photo- and video-techniques, the software enabling to easily change and stylize both images and sound, opened new oppor- 
tunities. Now a spectator may not just perceive and contemplate but take a more active position alongside with the author, and even become a co-author. A repost, a like - and a consumer is "closer" to the author, while in case of a witty comment, moreover an ironical parody, they are almost equal to the author. That is why, in case of network culture, every active Internet user is "one's own director", as well as an artist, a photographer, a writer, even a producer and marketer.

We are not apt to overestimate the scale, significance and, moreover, esthetic value of such creative activity of Internet users. It is obvious, however, that till recently there has never been such a symmetrical, bilateral interaction of author and spectator in the history of art.

The transformation of the "author-spectator" relation makes one look at a different angle at the post-structural concept of the death of the author, formulated several decades before social media appeared. On the one hand, appearance of the new media created technical abilities for this idea transition from the sphere of philosophical abstractions to the space of everyday life and for turning it into a sort of routine social practices. On the other hand, the sociocultural reality formed in the virtual space makes one reconsider the understanding of authorship which reigned in the European culture since Gutenberg's epoch. "The author has not died, but moved to Facebook", noted Martynov (2015, p. 4). It means that social media do not just free the "text" from the supremacy, "tyranny" of the authorship (Barthes, 1967) in the limit they erase the boundaries between the author and the spectator/reader. In the space of social media, the source of new meanings is not so much the author's text as the context per se (network culture and network community). The latter allows the text accreting commentaries, interpretations and parodies (some of which sometimes surpass the text by the depth and artistic means).

\subsection{New media art as a communicative object}

Development of the modern digital communicative technologies changes not only the forms and methods but also the functions of art, which has more than once occurred in the history of art, though. For example, according to Benjamin, in the "pre-technical" epoch the main function of a work of art was to serve a magic ritual, then, with occurrence of religion - a religious ritual. As for the esthetic component of art, it was insignificant and served an auxiliary function. Many works of art, especially in cult establishments, remained unavailable to the mass audience and were used only during sacramental rituals. Starting from the Renaissance period, under secularization of culture, the expositional potential of a work of art became more and more relevant. Even in Vatican City of the 18th century, a picture gallery was opened that started, which later became the central museum of the Byzantine and European paintings of the 11th-19th centuries in Vatican City. As a consequence of invention of technical means of serial reproduction, art becomes accessible and popular, which, alongside with its expositional potential, starts being used as a means of agitation and propaganda.

However, under the network culture, ideological function of art decreases. The efficiency of political propaganda is only possible under uncritical perception, which is significantly minimized, if not totally excluded, under the network culture. Under the new conditions, the asymmetry of the active "author-passive spectator" relations is leveled; the dominating 
author's position, which excludes or discredits the alternative viewpoints and different artistic interpretations, also disappears. A specific feature of network communication (including by means of a work of art) is symmetry of relations, equality of all participants, and abundance of alternative sources and channels of information. All this actually excludes control over the content of cultural communication, making it impossible to use the latter as a means of political propaganda and agitation.

Under the modern conditions of network culture, a significant function of a work of art is communication. Network communication, Internet communication are a special type of communication, the goal of which has already transformed into an end in itself and is reduced to the very fact of contact, not implying any further actions or solving specific tasks. Network communication may link people who are not linked by anything else: no common views, preferences, interests, or needs.

Turning into a communicative object, a work of art in the Web undergoes a specific "negative filtration", or specific kinds of mediation. The first mediation, let us conditionally call it a "social-network" one, means that existence and spreading of a work of art in the Web, being "reposted" and "shared", accumulates comments, forming an averaged collective opinion of the communicative community. This impersonalized public opinion is, as a rule, a significant factor of personal perception and assessment of an individual subject. Thus, the dual relations of the "author-spectator" turn into triad relations "author-communicative community-spectator". In such situation, the artistic value of the work of art per se becomes secondary, and sometimes even excessive.

This idea can be illustrated by the example of a film Matilda (2017) by a Russian film director Alexei Uchitel, which tells about the relations between a heir to the throne, the would-be Nicolas II of Russia and a ballet dancer Mathilde Kschessinska. The film aroused a broad scandalous resonance in Russia even before it was shown in cinemas and became the object of heated discussion, including in the Internet. Here is one of the reader's comments to the film Matilda published in an Ogonek magazine:

\footnotetext{
"It seems that the main result of 'Matildiada', which gripped the country, is the emergence of the phenomenon of a pre-screen film. It does not exist yet, but it has been already seen. Felt. Praised with applause. Or accompanied by curses [...]. There is hardly any sense in going to the cinema then. The impression has occurred. What can the film strip add to it? It has invariably lagged behind the already obtained feeling of the film. It is not needed already" (Mel'nikov, 2017).
}

The film distribution confirms this point of view. By the 2019 data, the film Matilda became the most unprofitable film supported by the Cinema Foundation of Russia: "Matilda's losses became a sort of a record - 550 million rubles" (Zhitkova, 2018).

The second type of mediation of a work of art under network culture can be conditionally called technical, as in this case mediation is related to the technological aspects of storing, reproducing, translation and consumption of the works of art. On the one hand, network formats of communication approximate a work of art to a spectator, making it more accessible and cheap. That was noticed by Benjamin as early as in the epoch of pre-digital reproduction of art: technical reproduction "allows an original making a move towards the public" (1936) in the form of a photograph or a gramophone record. Under modern conditions, art 
became even "closer" to a spectator. However, such "proximity" has its negative reverse side. Accessibility of an artistic creation, limitedness of its spatial-temporal presence in the sight of a spectator the size of a smart phone screen, reduces all physical, psychological, financial efforts and expenditures of a consumer of art to a movement of a cursor on a monitor. The specific aura of art disappears, as well as its transcending potential, pathos, i.e. everything which is traditionally defined as the magic power of art and which allows ascending above the daily routine.

Thus, under network culture an artistic creation turns into a communicative object, while meeting of a spectator with a work of art becomes mediated both by network communicative community and digital technologies. That is why, despite the availability and seeming proximity of a work of art to a modern spectator, they are actually metaphysically alienated from artistic creation. Obtaining an artistic creation with a click of a mouse, without extra efforts and expenditures, a spectator actually looses more than acquires: they rob themselves, depriving themselves of the plenitude of esthetic feelings.

\subsection{Dominating of irony in the space of network culture}

One of the consequences of such alienation of a spectator from artistic creation is domination of ironic attitude to art in the Net.

Interpreted in philosophical sense, irony indicates implicit non-acceptance of reality, depriving the situation of the status of reality, legality and seriousness with its explicit (demonstrated) acceptance and approval.

A feature of implementing ironic attitude in network communication is, first, that it cannot always be recognized and detected in this context. In live communication, the ironic character of an utterance is, as a rule, rather obvious. Knowing the context of the utterance, the personality of the author (gender, age, world outlook, education, etc.), indirect nonverbal signs (facial expression, gestures, intonation) - all this allows to rather accurately decide whether the utterance should be perceived in direct, literal sense or it contains implicit mockery, play upon words and meanings. As the mentioned concomitant factors of communication are lacking in online communication, it is often impossible to identify irony as irony and demarcate it from a serious utterance.

Second, in the space of network culture a user may purposefully create the ironic attitude, or it may appear involuntarily, as a side effect. As it was stated, in the network communication "irony appears as an echo, as a result of referring, in a new context to what had been said earlier" (Sanina, 2015, pp. 83-84). As a result of digitalization, an artistic creation not just loses its original context, indicating its sources, but has the opportunity to acquire new interpretations to a much greater extent than before. In the course of numerous "reposting" and "sharing", unexpected meanings, links and senses are revealed. This is a peculiar echo effect, inevitably appearing in network culture.

Besides, a work of art is being repeatedly commented in the Net. Re-actualization per se of an artistic creation in network culture occurs when it provides reason for communication, which may be extensive or laconic, lead to increase or decline of interest in the work of art. Due to its rhizomatic nature, network communication does not form a hierarchy among communicants, enabling to openly doubt all commentaries or confirm them as obvious. In 
any case, a user, perceiving a work of art, enters a large field of existing interpretations, which apparently (if one agrees with Anna Sanina) is a grounds for ironic attitude:

"The situation is considered ironic if it was designed as having a bi-coherent structure and causes the corresponding forms of emotions. In other words, the sense of irony is formed through our perception of the situation, with the account of other people's perception, which we can easily observe, for instance, in our own Friends Page" (2015, p. 84).

Thus, a work of art is initially perceived as something obligatorily ironic in meaning. This ambivalence also influences the feelings of a spectator, who becomes distanced from their own esthetic reflection and becomes a decentralized subject of esthetic perception. Now a person treats seriously neither a work of art nor the emotions it causes in oneself.

Third, as irony cannot be distinctly differentiated or grasped "directly" (unambiguous definition of the situation or utterance as ironic), it becomes potentially total in the Internet. In other words, in online sphere it is impossible to draw a distinct line between a seriously unambiguous, literal content of a phenomenon or utterance and their ironic interpretation. Almost any utterance, photo, or post may be understood as having ironic content, even if it was not implied by the author. This regularity is a consequence from the so called "Poe's law" 2 based on a comment written by Nathan Poe in 2005 on an English-language Internet forum on Christianity during a debate on creationism. In the original wording, the law read as follows:

"Without a winking smiley or other blatant display of humor, it is utterly impossible to parody a Creationist in such a way that someone won't mistake for the genuine article" (Wikipedia: The Free Encyclopedia, 2019).

Notably, while the presence of a smiley (Garber, 2013) or direct mention of the said law do indicate the need to interpret some utterances as ironical, their absence does not exclude the ironic message, does not indicate that the utterance or situation should be perceived literally. Thus, in the situation of anonymous communication and communicative "echo" (change of context or utterance) it becomes impossible to unambiguously recognize irony. Any ironic message may be read as a serious, sincere statement; and vice versa, any sincere statement, provided it seems improbable or inappropriate to a reader, may be interpreted as irony.

The ironic attitude, which deprives high art of its elite status, may at the same time have advantageous influence on the perception of mass artistic product. Kitsch is always serious in its imitation of genuine art. The ironic attitude to kitsch, the inevitable distance of assessment, which a user takes up, allows creating the necessary portion of criticism, thus provoking reflection and comprehension of mass culture. As a result, a demand for more sophisticated esthetic feelings may be revealed to a spectator of a mass work of art.

However, in both cases the ironic attitude generates additional meanings and senses, making a spectator see something other than what was implied by the author. At that, taking into account the potentially total character of irony in the Internet, we may conclude that within network culture the very environment, the context of existence and reproduction of an artistic creation is creatively charged, i.e., they produce a certain "added esthetic value".

\footnotetext{
${ }^{2}$ Poe's law as a variation of professional humour is an adage of the Internet users, however, this law has already become the subject of serious academic research (LaMarre et al., 2009).
} 


\subsection{Creativity as creation ex nihilo and/or as bricolage}

In his work "The Work of Art in the Age of Mechanical Reproduction" Benjamin stated that appearance of cinematography and photography makes one review the very notion of art. Today, when almost a century passed after those words were written, we may suppose that the appearance of network culture as a media capable of reproducing aesthetic content, as well as new media art with their specific ontology, makes us if not review then at least broaden the very notion of creativity, which is generic for artistic creativity.

In the broadest sense, creativity is traditionally understood as making something new. Turning to manifold definitions of this phenomenon, we may notice that, despite all differences, they have common basis of meaning: creativity as making something new out of nothing. We may just suppose that this understanding of creativity became basic for the cultures descending from the traditions of Abrahamic religions. The divine creativity ex nihilo, being interpreted in secular and humanistic sense during the Renaissance period, became perceived as a prototype, a kind of a matrix of human creativity. However, beginning from the 20th century, artistic culture demonstrates that a different revelation of creativity is possible - creativity as "remaking", "revision". This is not about making something new out of nothing, but more about working with material at hand. The ontological model of such new interpretation of creativity is probably the bricolage technique described by Lévi-Strauss.

Bricolage is one of the key Lévi-Strauss' notions, denoting a special technique of activity in preset conditions, under limited set of resources:

"The 'bricoleur' is adept at performing a large number of diverse tasks; but unlike the engineer, he does not subordinate each of them to the availability of raw materials and tools conceived and procured for the purpose of the project. His universe of instruments is closed and rules of the game are always to make do with 'wharever is at hand"' (1966, p. 17).

A bricoleur acts with the "remains", "debris" of cultural and historic events, the meaning of which had been originally set by previous epochs.

Apparently, in bricolage the ability for creativity is "separated" from the figure of the author and is disseminated around the whole cultural space, including technical means of reproduction; it becomes a derivative from certain repeated structures; thus, the author is divested of their priority status. The specificity of creativity by bricolage model is not only in its fragmentary-patchwork character, but also its anti-narrative property. Narration implies linearity, while the reference point is set by the author, who builds and centers the plot on oneself. Narrativity is inherent to creativity in its classical sense, when creativity is interpreted as making something new out of nothing. Here, it is the author that is the ontological basis of creation, thus, the author obtains the priority in relation to all other participants of artistic creativity (the environment, the context, the spectator), as well as the right to set the logic of narration. In turn, creativity as bricolage breaks the logic of narrativity, as it rejects the ontological privilege of the author's position. Anti-narrativity of bricolage, first, makes an artistic work, performed in compliance with this model, mosaic, kaleidoscopic, lacking any priority or central position. Second, anti-narrativity makes narration open, disconnected, as a creation without a plot has neither a logical beginning (outset), nor ending. 
Creativity understood as bricolage is implemented in the art of postmodernism, with its inherent principles of citation, irony, deconstruction, synthetic genres, etc. Supposedly, the first artistic experiments performed according to bricolage model were pop-art, trashart, etc. In network culture, bricolage as a model of creativity acquires new possibilities for implementation.

Thus, in the context of network culture, the environment per se sets the patterns of perceiving works of art by a spectator. For example, the digital technologies as new means of technical reproduction, the social networks turning any user into a co-author of a work of art, the communication as the main function of art and the communicative echo generated by it, the ironic attitude acquiring potentially total character - all this necessarily facilitates a certain accruement of meaning, a different interpretation of the esthetic content of creation. Getting into the space of network culture, any image accrues certain additional meanings and ideas, which sometimes may exceed what was initially preset by the author in terms of depth and artistic means, or may discord with it.

Is it correct to refer these new meanings, this "added esthetic value", generated by the network culture as a specific environment, to a category of creativity? To answer this question, we turn to speculations of an artist Kandinsky about the essence of art. In his work Concerning the Spiritual in Art he wrote: "Every work of art is the child of its age and, in many cases, the mother of our emotions" (1910). The outstanding artist of the 20th century emphasized that art is not just generated by the historical epoch and reflects it, but should evoke certain feelings in a spectator. To the extent new media art corresponds to these two conditions, we may refer it to the category of art.

Undoubtedly the new things generated here do not correspond to the definition of creativity in its traditional interpretation - it is creativity as bricolage or some other type. The authors do not claim to have radically reviewed the notion of creativity - we just speak of broadening the volume of this notion, it comprising the new types of creativity implemented in the modern world, including in the space of network culture, as in the case of bricolage.

The authors are prepared to face doubts and even objections which may occur in a reader concerning the ability of network culture and modern art to be "the mother of emotions". Indeed, one cannot but agree with the idea by Kandinsky that the true art should have "a deep and powerful prophetic strength" (1910). Therefore, art requires of the author, as well as of the spectator, certain spiritual efforts and emotional tension. If one stems from these qualities, credited to the true art as attributive ones, then browsing the websites, hanging up in social networks, hyperactivity in blogs can hardly be equaled to the spiritual work performed by a spectator during live meeting with art in its classical sense. In this case, the only way out, which seems to be almost obvious, is to search for the true art and creativity beyond the Web. And even beyond the new technologies, which in this sense, according to Kačerauskas, become a "means of leveling the creative activity instead of promoting creativity", a sort of "an index of anti-creativity" (2017, p. 32). However, this recommendation is as obvious as unrealistic. And the problem is not in the utopist character of this idea - even if it is hard to imagine a modern person voluntarily refusing from all conveniences of digitalization, cinematography will obligingly offer numerous apocalyptic scenarios of humanity returning to the pre-digital and even pre-technical epoch. In our opinion, the most serious obstacle is that today network culture is no longer a context, an external condition of hu- 
man existence, but is built into the inner world, which is especially vivid in young people, starting from the millennial generation. Being interiorized, network culture not from without but from within determines the way of thinking, the means of perceiving information and working with it, the patterns of communication, the language picture of the world, the artistic-esthetic language (the system of cultural symbols and codes). Digital technologies of communication determine even the sensual perception of a modern person, including perception of time, space, and motion, thus setting the "parameters" of their meetings with the beautiful. Therefore, however primitive new media art may seem compared to traditional art and however doubtful the creative potential of bricolage may seem compared to creation from nothing - the return to pre-digital culture is hardly possible, as neither the author not the spectator, nor the understanding of art and creativity per se will ever be the same. Thus, even if we express solidarity with Benjamin in his nostalgia about the aura of the "authentic", "original", and "genuine", we should understand that this nostalgia is just "a dream of the lost truth" (Eisenman, 1995, p. 182).

\section{Conclusions}

Development of digital communication technologies change the ontology of modern art: the means of creating, storing and reproducing works of art, as well as the laws of perception. First, the "author-spectator" relationships change. Under social media, each Internet user is not only a consumer of cultural benefits, art in particular, but also their co-author, at the very least. In the space of social media, it is possible to erase the boundaries between the author and the spectator/reader, while the source of new meanings is not so much an author's text as the context per se (network culture and network community).

Second, under network culture a work of art turns into a communicative object, while a meeting of a spectator with a work of art becomes mediated by both the network community and the digital technologies. This leads to distancing, metaphysical dissociating of a spectator from a work of art.

Third, one of the consequences of such metaphysical dissociating of a spectator from a work of art is ironic attitude to art prevailing in the Internet. Irony in the web appears as a result of the cultural "echo", while the esthetic value of a work of art as a communicative object becomes not so significant, and sometimes even excessive.

Fourth, the bricolage model of creativity becomes relevant for new media art; its methodological basis if the concept of "bricolage" developed by Lévi-Strauss. Creativity understood as bricolage, fragmentary-patchwork and anti-narrative in its essence, finds implementation in the art of postmodernism.

\section{References}

Barbrook, R., \& Cameron, A. (1996). The Californian ideology. Science as Culture, 6(1), 44-72. https://doi.org/10.1080/09505439609526455

Barthes, R. (1967). The death of the author, Aspen 5-6. http://www.ubu.com/aspen/aspen5and6/threeEssays.html\#barthes 
Baudrillard, J. (2007). In the shadow of the silent majorities. Series: Semiotext(e) Foreign Agents Series. Semiotext(e).

Bell, D. (1973). The coming of post-industrial society: A venture in social forecasting. Basic Books.

Benjamin, W. (1936). The work of art in the age of mechanical reproduction. https://www.marxists.org/ reference/subject/philosophy/works/ge/benjamin.htm

Boyd, D. M., \& Ellison, N. B. (2007). Social network sites: Definition, history, and scholarship. Journal of Computer-Mediated Communication, 13(1), 210-230. https://doi.org/10.1111/j.1083-6101.2007.00393.x

Campanelli, V. (2010). Web aesthetics: How digital media affect culture and society. NAI Publishers.

Carr, N. G. (2004). Does IT matter? Information technology and the corrosion of competitive advantage. Harvard Business School Publishing Corporation. https://doi.org/10.1145/1022348.1022349

Castells, M. (2000). The information age: Economy, society, and culture. Vol. III: End of Millennium. Blackwell Publishers.

Castells, M. (2001). The internet galaxy: Reflections on the internet, business, and society. Oxford University Press.

Coeckelbergh, M. (2018). The art, poetics, and grammar of technological innovation as practice, process, and performance. AI and Society: Journal of Knowledge, Culture and Communication, 33, 501-510. https://doi.org/10.1007/s00146-017-0714-7

Eisenman, P. (1995). Aura und Exzeß: Zur Überwindung der Metaphysik der Architektur. Passagen Verlag.

Erofeeva, M. A., \& Fiodorov, A. A. (2014). Proizvodstvo i potreblenie izobrazhenij v cifrovuju epohu. Labirint: Zhurnal social'no-gumanitarnyh issledovanij, 2, 147-157.

Florida, R. (2002). The rise of creative class, and how it's transforming work, leisure, community, and everyday life. Basic Books.

Fürst, G., Ghisletta, P., \& Lubart, T. (2012). The creative process in visual art: A longitudinal multivariate study. Creativity Research Journal, 24(4), 283-295. https://doi.org/10.1080/10400419.2012.729999

Garber, M. (2013). How to tell a joke on the internet: The new typography of irony. The Atlantic. https://www.theatlantic.com/magazine/archive/2013/05/how-to-tell-a-joke-on-the-internet/309293/

Howkins, J. (2007). The creative economy: How people make money from ideas. Penguin.

Kačerauskas, T. (2009). Ekran i jekzistencial’noe tvorchestvo. Vestnik Buryatskogo gosudarstvennogo universiteta. Pedagogika. Filologiya. Filosofiya 6, 91-96.

Kačerauskas, T. (2017). Kreativnost' i koncepciya kreativnogo obshhestva v sociologii. Sotsiologicheskiye issledovaniya, 10, 26-35. https://doi.org/10.7868/S0132162517100038

Kandinsky, W. (1910). Concerning the spiritual in art - Part 1. https://arthistoryproject.com/artists/ wassily-kandinsky/concerning-the-spiritual-in-art-part-1/

LaMarre, H. L., Landreville, K., D., \& Beam, M. A. (2009). The irony of satire: Political ideology and the motivation to see what you want to see in the Colbert report. The International Journal of Press/ Politics, 14(2), 212-231. https://doi.org/10.1177/1940161208330904

Lavrinec, J. (2014). Community art initiatives as a form of participatory research: The case of street mosaic workshop. Creativity Studies, 7(1), 52-65. https://doi.org/10.3846/20297475.2014.933365

Lévi-Strauss, C. (1966). The savage mind. The University of Chicago Press.

Lovink, G. (2009). Dynamics of critical internet culture (1994-2001). Institute of Network Cultures.

Lovink, G. (2013). A world beyond Facebook: Introduction to the Unlike Us Reader. In G. Lovink \& M. Rasch (Eds.), Unlike us reader: Social media monopolies and their alternatives (pp. 9-15). Joh. Enschedé.

Manovich, L. (2003). New media from Borges to HTML. In N. Wardrip-Fruin \& N. Montfort (Eds.), The new media reader. MIT Press, 13-25. 
Manovich, L. (2013). Software takes command. Series: International texts in critical media aesthetics. F. J. Ricardo (Founding Ed.). Vol. 5. Bloomsbury Academic.

Manovich, L. (2017). Teorii soft-kul'tury. Krasnaya lastochka.

Martynov, K. (2015). Vek pisateley: tekst i pis'mo v novykh media. Logos, 25(2), 1-11.

McLuhan, M. (1964). Understanding media: The extensions of man. McGraw Hill.

McLuhan, M., \& Fiore, Q. (1967). The medium is the massage: An inventory of effects. Random House.

Mel'nikov, A. (2017). Doekrannoe kino. Kommersant. https://www.kommersant.ru/amp/3450138

Pryshchenko, S. V. (2019). Creative technologies in advertising design. Creativity Studies, 12(1), 146165. https://doi.org/10.3846/cs.2019.8403

Safina, A. M. (2017). Setevaja kul'tura kak produkt i uslovie razvitija setevyh soobshhestv. Vestnik Severnogo (Arkticheskogo) federal'nogo universiteta. Serija Gumanitarnye i social'nye nauki, 5, 87-95.

Safina, A. M., Leontyev, G. D., Gaynullina, L. F., Leontyeva, L. S., \& Khalilova, T. V. (2018). Dialectics of freedom and alienation in the space of the internet. Revista ESPACIOS, 39(27). http://www. revistaespacios.com/a18v39n27/a18v39n27p08.pdf

Sanina, A. (2015). Vizual'naja politicheskaja ironija v Runete: kejs soobshhestva "Potsreotizm”, INTER: interakciya, intervyu, interpretaciya, 7(9), 79-95.

Shanken, E. A. (2016). Contemporary art and new media: Digital divide or hybrid discourse? In Ch. Paul (Ed.), A Companion to digital art (pp. 463-481). Series: Wiley Blackwell Companions to Art History. John Wiley \& Sons, Inc.. https://doi.org/10.1002/9781118475249.ch21

Skidan, A. (2007). Pojezija v epohu total'noj kommunikacii. Vozduh 2. http://www.litkarta.ru/projects/ vozdukh/issues/2007-2/skidan/

Toffler, A. (1980). The third wave: The classic study of tomorrow. Bantam Books.

Wikipedia: The Free Encyclopedia. (2019). Poe's Law. https://en.wikipedia.org/wiki/Poe\%27s_law

Zhitkova, D. (2018). Kto otvetit za "Smert' Stalina": sbory i ubytki rossiyskogo kinoprokata. https://www. forbes.ru/forbeslife/356237-kto-otvetit-za-smert-stalina-sbory-i-ubytki-rossiyskogo-kinoprokata

\title{
MENO KÜRINYS TINKLO KULTŪROS ERDVE்JE: KÜRYBIŠKUMAS KAIP BRIKOLIAŽAS
}

\author{
Aynur SAFINA, Liliana GAYNULLINA, Ekaterina CHEREPANOVA
}

\section{Santrauka}

Tobulëjant moderniosioms informacijos ir komunikacijos technologijoms, atsirado naujas unikalus sociokultūrinis reiškinys - tinklo kultūra, kur vyraujanti retorika yra ironija. Tinklo kultūros erdveje skaitmeninių technologijų sąlygomis keičiasi meno formos, rūšys ir funkcijos bei kūrybiškumas apskritai. Straipsnyje teigiama, kad komunikacija tampa pagrindine meno funkcija, o meno kūrinys - kuo toliau, tuo labiau virsta komunikacijos objektu. Autoriai siūlo išplèsti kūrybiškumo koncepcijos apimtị, peržengiant klasikinę interpretaciją, siekiant platesnio šio reiškinio supratimo, o būtent kūrybiškumo kaip brikoliažo. Kūrybiškumo brikoliažo modelio metodologinis pagrindas, aktualus naujųjų medijų menui, tai „brikoliažo“ koncepcija, išplètota Claude’o Lévi-Strausso.

Reikšminiai žodžiai: brikoliažas, komunikacija, kūryba, ironija, tinkle kultūra, naujųjų medijų menas. 